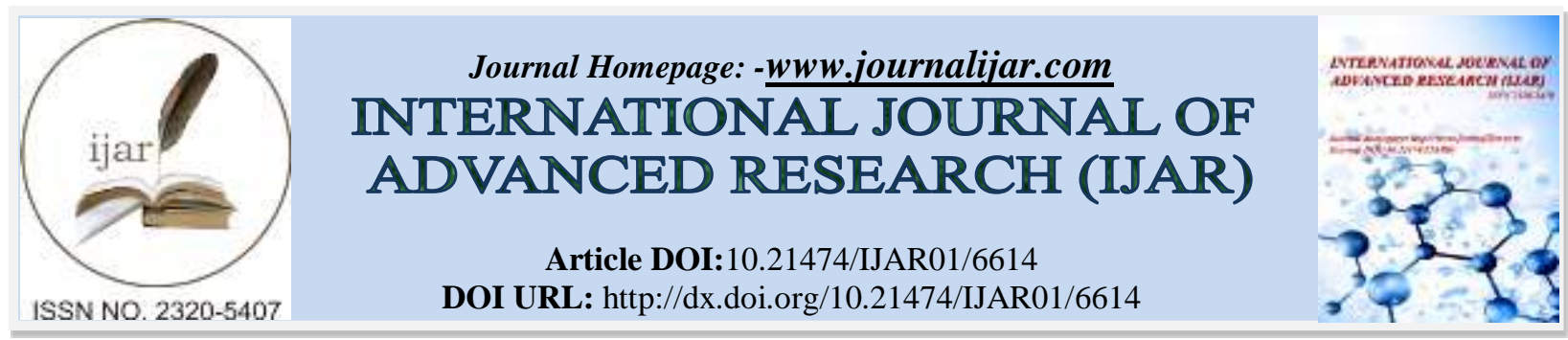

RESEARCH ARTICLE

\title{
PLANTING CORN THE EARTH-FRIENDLY WAY: USE OF BIO-FERTILIZERS AND PLANT-BASED INSECTICIDES IN CULTIVATING GREEN CORN AT LAGUNA, PHILIPPINES.
}

Lolita I. Beato.

Phd, Laguna State Polytechnic University, Siniloan, Laguna, Philippines.

\section{Manuscript Info}

Manuscript History

Received: 23 December 2017

Final Accepted: 25 January 2018

Published: February 2018

Keywords:-

Green corn, biofertilizers, plant-based insecticides, Makabuhay,

\begin{abstract}
Corn (Zea mays) is one of the major crops grown in the Philippines. However, most farmers, particularly those in the province of Laguna, still use inorganic fertilizers and insecticides, a practice that could lead to adverse ecological consequences. Hence, this study sought to find an "earth-friendly" way of cultivating green corn by using bio-fertilizers and plant-based insecticides. A $2 \times 4 \times 6$ factorial experiment, following a split-split plot design with three replications, was conducted. Results showed that a fertilizer mix of $571.43 \mathrm{~kg}$ Greenland/ha (chicken manure compost $)+180.96 \mathrm{~kg}$ Urea/ha was comparable with $192.86 \mathrm{~kg}$ (14-14-14)/ha $+140 \mathrm{~kg}$ Urea/ha (inorganic fertilizer treatment) and better than $1413.6 \mathrm{~kg}$ Vermicompost $/ \mathrm{ha}+140 \mathrm{~kg}$ Urea/ha in affecting the growth and yield performance of green corn, specifically in terms of plant height, number of days to 50 percent silking, number of corn ears per plant, and length and diameter of unhusked corn ear. Moreover, it was found that using $571.43 \mathrm{~kg}$ Greenland/ha yielded 20.82 tons of unhusked corn ears per hectare, which is only slightly lower than the 23.18 tons produced by $192.86 \mathrm{~kg}$ (14-14-14)/ha +140 $\mathrm{kg}$ Urea/ha, noting that the Control only yielded 16.81 tons per hectare. Meanwhile, it was found that using $1041.67 \mathrm{li} / \mathrm{ha}$ Makabuhay (Tinospora rumphii Boerl) vine extract (organic insecticide) was comparable with $1041.67 \mathrm{tbsp} / \mathrm{ha}$ Lannate (Methomyl) in addressing insect infestation and population from whorling to silking, silking to maturity, number of larvae per plant, and number of borers per stem. The Makabuhay vine extract was also found to be better than Lannate when it comes to controlling insect infestation, as indicated by the number of nymphs per corn ear and number of nymphs per plant. The study recommends further testing of the Makabuhay vine extract in different concentrations, as well as using fertilizer combinations in other corn varieties.

Copy Right, IJAR, 2018,. All rights reserved.
\end{abstract}

\section{Introduction:-}

Corn (Zea mays) is one of the major crops grown in the Philippines and considered as the second most important staple food for the Filipinos. The growth of the corn industry is associated not only with growing population but also with that of poultry and livestock sectors. Corn is also processed into high value products, such as corn starch, corn oil, gluten, and snack foods. 
With this information on the varied uses of corn and corn by-products, there is really a need to increase corn production per unit area. This could be attained by supplying the appropriate kind and amount of nutrients and insecticides to the corn plants for optimum growth, development and production. The farmers, particularly those from Laguna, usually provide these nutrients through application of inorganic fertilizers and insecticides. However, the Philippines Strategy for Sustainable Development (PSSD) of the Development of Environmental and Natural Resources DENR (1990) mentioned that continuous and over application of inorganic fertilizers might increase soil acidity, which affects nutrients availability while insecticides might kill not only harmful insects but even the beneficial insects. Besides, utilization of chemical based insecticides may contaminate the soil, air, water and foods which may endanger human health.

\section{Background of the Study:-}

Maximum corn production could be attained by following recommended technologies or cultural practices like seed nitrogen inoculation, sources of nutrients and utilization of an efficient and economical method of controlling insect pests and diseases.

Utilization of Bio-N. Bio-N is a biofertilizer derived from the bacterium Azospirillium isolated from the roots of a local grass "talahib" (Saccharum spontaneum Linn). It can be applied easily by coating into seeds before sowing. The bacteria can enhance root development, growth and yield of corn. This reduces the use of costly inorganic or chemical nitrogen fertilizer. Using Bio-N is not only environmentally safe but also increases the net income of farmers.

Utilization of natural farming inputs such as Organic fertilizers. These are sources of nutrients derived from animal by-products and excreta, green manure, crop residues, household's organic wastes, etc. Products processed from these materials could be compost, vermicompost and organic foliar fertilizer, etc.

Use of plant-based environmental friendly insecticides and pesticides for the control of insects and other pests, accompanied with proper cultural practices in crop production. Insects attack all growth stages of corn in the field, and can reduce yield by as much as 20 to $80 \%$.

Botanical insecticides could be derived or extracted from plants which possess pesticidal properties like neem leaves (Azadirachta indica), Makabuhay vine (Tinospora rumpii Boerl), madre de cacao leaves (Gliciridia sepium), and marigold leaves (Calendula officinalis) which are always available in the localities and nearby communities. As reported by Sangatanan and Sangatanan (2000), these plants contain pyrethroid, rotenone, nicotine, neem, isoflavanoids, saponin, alkaloids and many more that are essentially active components of insecticides

Even though several organic fertilizers and insecticides have been produced and introduced, still most farmers utilized inorganic fertilizers and insecticides in crop production in spite of the rapid increase in prices. This indicates that farmers are still unaware and/or unconvinced of the benefits that could be derived from the utilization of organic farm inputs. Thus, this study was to emphasize the significance of organic fertilizers and pesticides not only in increasing profits on agricultural production but also contribute on the conservation of the environment.

\section{Oganic Crop Production:-}

Organic farming is an ecological production system that promotes and enhances biodiversity and relies on minimal off-farm inputs such as chemical fertilizers and pesticides.

Important considerations in organic farming are as follows:

1. In order for Organic Farming to be economically viable, there should be clear strategies to maintain soil fertility.

2. Replenish the nutrients removed at harvest to sustain productivity.

3. Minimize fertility mining and nutrient losses in order to sustain yields and optimize nutrient

4. In regard to supplementation, the rich biodiversity as well as natural subsidies as biological nitrogen fixation, etc. should be exploited to the possible extent; and,

5. Insecticidal, fungicidal, and bactericidal properties of the flora and fauna, and tree species need to be exploited for pests and diseases.

Importance of Organic Fertilizer:-

Organic fertilizers are by no less inferior to that of inorganic fertilizers. 
1. Their long lasting conditioning property on chemical, physical, and biological characteristics makes them beneficial to use.

2. Organic fertilizers offer no over dose and adverse residue effect than that of inorganic fertilizer.

3. Organic fertilization or compost application replenishes soil organic matter being depleted with continuous cropping. Its application activates soil microorganisms which consequently increase the availability of nutrients in the soil (PCARRD, 1983).

\section{Disadvantages of Using Organic Fertilizer:-}

1. Low percentage of major plant nutrient (NPK) with high moisture content,

2. Requires large quantities to apply alone in order to meet the crop fertilizer requirement

3. Too bulky to handle, entailing additional cost in handling, transport, and field application

4. If applied when not freely decomposed, tends to induce nutritional deficiency in the plants .Dagoon and Sangatanan( 1990 ).

\section{Biological Nitrogen Fertilizer:-}

1. Bio-N contains Azospirillum, or nitrogen-fixing bacterium isolated from the roots of talahib grass (Sascharum spontarium L.). It has been found to be an effective inoculant for rice, maize, sugarcane, potato, and tomato SEARCA (1998)

2. Experiments show that Bio-N maintains high nitrogen levels through to harvest, resulting in denser root production. Tests conducted in the uplands indicate that Bio-N can provide up to $50 \%$ substitution for inorganic nitrogen fertilizer SEARCA (1998).

\section{Balanced Fertilization Strategy:-}

It is the optimum use of organic and inorganic fertilization with the proper grade and amount which ensure a sustained high crop yields over long cropping seasons.

\section{Biofertilizers:-}

These are the products containing living cells of different types of microorganisms (bacteria, fungi, actinomycetes, etc.) which have the ability to fix atmospheric nitrogen and mobilize phosphorous in the soil from unavailable form to plant usable form . PCCARD ( 1998 )

1. Benefits from using biofertilizers includes increase crop yield by 20-30\%, replace chemical nitrogen and phosphorous by $25 \%$, stimulate plant growth, activate the soil biologically, restore natural soil fertility, and provide protection against drought and some soil born diseases PCCARD ( 1998 )

2. Advantages of biofertilizers includes cost effective, supplement to fertilizers, eco-friendly, and reduces the costs towards fertilizer use, especially regarding nitrogen and phosphorous and in safeguarding the soil health and also the quality of crop products. PCCARD ( 1998 )

\section{Biological Nitrogen Fixers (BNF):-}

The inoculants under the trade name Bio-N is now being commercialized by BIOTECH which is specifically used for rice and corn. This biofertilizer enhances growth and development of plants and provided $30-50 \%$ of their nitrogen requirements (Navarro, 2000). This bacterium was initially isolated from the grass talahib (Saccharum spontaneum Linn.). Grain yield may be increased by as much as $30 \%$ compared to unfertilized treatments.

\section{Botanical Plants as Source of Pesticides:-}

1. Bio pesticides, according to Waage (1997), are certain types of pesticides derived from such natural materials as animals, plants, bacteria, and certain minerals.

2. Bio pesticides generally exhibit the following characteristics:

1. Have a narrow target range and highly-specific mode of action;

2. Slow activity;

3. Suppress (rather than eliminate) pest populations;

4. Generally, safer to humans and the environment than conventional pesticides since these are inherently less toxic than conventional pesticides

5. No residue problems.

6. Often are effective in very small quantities 
7. It often decompose quickly, thereby resulting in lower exposures and largely avoiding the pollution problems caused by conventional pesticides.

\section{Related Studies:-}

1. A significant increase in corn yield was obtained when either ipil-ipil biomass or commercial fertilizer was applied (Cosico,1991).

2. Potash application has a significant effect in the growth and development of corn in the field compared with the treatment without K use, i, e. with $\mathrm{N}$ and P only (Sikara et al. 2001).

3. Neem tree leaf extract could be an effective source of insecticides on corn plants under intercropping system. It could be effective to reduce the number of corn seedlings maggot and percent corn infestation with corn semi looper and increased the number of beneficial insects per plot thus, resulted to higher yield per hectare in peso (Viyar, 2005).

4. All growth and yield response of corn was affected by fertilization treatment (Nebrida, 1993).

\section{Conceptual Framework of the Study:-}

1. The first frame shows the inputs which are actually the independent variables which include the inoculants, bioorganic fertilizers, and insecticides as shown in Figure 1.

2. The second frame presents the output which includes the growth and yield performance of green corn as affected by inoculation and different bio-organic fertilizers and insecticides.

3. It is assumed that the lesser the chemical-based fertilizer and pesticide application, the lesser the agricultural pollution which is important in the conservation of environmental resources.

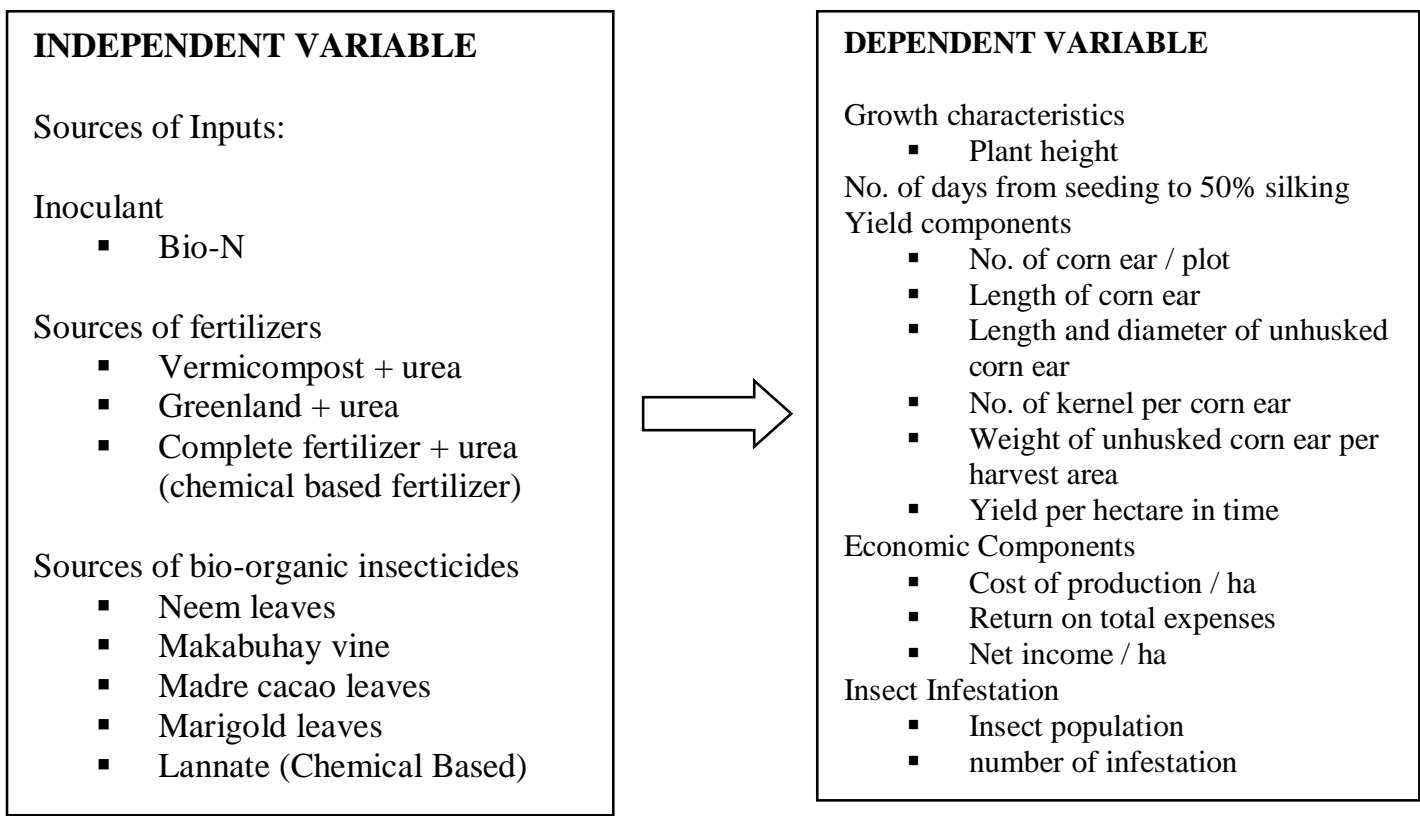

Figure 1:- Conceptual framework of the study.

\section{Statement of the Problem:-}

This study was conducted to determine the effects of bio-organic fertilizers and insecticides on the growth and yield performance of inoculated and non-inoculated green corn. More specifically, this study sought to answer the following questions:

1. Which sources of nitrogen fertilizers gave better growth and yield performance of green corn in terms of average plant height, number, length, and diameter of corn ear, number of kernels/corn ear, weight of corn/1.5 sq $\mathrm{m}$ harvest area, computed yield of corn in $\mathrm{kg} / \mathrm{ha}$ and least insect pest infestation?

2. What is the effect of inoculants in the growth and yield performance of corn?

3. Which of the bio-organic insecticide sources in this study gave the least insect infestation and highest corn yield? 
4. Are there significant interactions effect between and among inoculants and sources of fertilizers (Factors $\mathrm{A} x$ $\mathrm{B}$ ); sources of fertilizers and insecticides (Factors B x C); and among inoculants, sources of fertilizers, and insecticides (Factors A x B x C)?

5. Which of the inoculants, sources of fertilizers, and insecticides was most economical in corn production?

\section{Hypotheses of the Study:-}

To provide guides in the interpretation of data, the following null hypotheses were formulated and subjected to a thorough study and investigation:

There are no significant differences on the effects of inoculants, sources of fertilizers and insecticides on corn in terms of:

1. Average plant height $(\mathrm{cm})$ at maturity

2. Average number of days from seeding to $50 \%$ silking

3. Average number of corn ear/plant

4. Average length and diameter $(\mathrm{cm})$ of unhusked corn ear

5. Average number of kernels/corn ear

6. Average weight of unhusked corn ear/1.5 sq m harvest area

7. Computed yield/ha (tons)

8. Insect pest population density and percentage of insect infestation

9. Cost and return analysis

There are no significant interaction effects between and among:

1. Inoculation and source of fertilizers (Factors A x B)

2. Inoculation and sources of insecticides (Factors $\mathrm{A} \times \mathrm{C}$ )

3. Sources of fertilizers and insecticides (Factors B x C); and

4. Inoculation, sources of nitrogen and insecticide (Factors A x B x C) in terms of height of corn, no. of days from seeding to 50\% silking, no. of corn ear/plant, length, and diameter of corn ear, no. of kernels/corn ear, weight of unhusked corn ear/ $1.5 \mathrm{~m}^{2}$ harvest area and yield/ha.

\section{Significance of the Study:-}

The results of this study may find potential contribution or practical applications in terms of benefiting the farmers, the academic and the agricultural sector as a whole since this will serve as an effective instrument in the information dissemination regarding the need to study the growth and yield performance of green corn using organic fertilizers and pesticides. Thus, helping the nation to attain its goal of food self-sufficiency and environment-friendly farming inputs for the conservation and sustainability of the environment.

\section{Materials And Methods:-}

This experiment was conducted at Brgy. Maytalang I, Lumban, Laguna from February to May 2010.

\section{Research Design:-}

A $2 \times 4 \times 6$ factorial experiment was used in this study following the split-split plot design with three replications. A $1,791 \mathrm{sq}$ m experimental area was divided into three blocks to represent the replication. Each block was divided into two main plots where inoculated and non-inoculated corn seeds were planted. Each main plot was divided into four subplots into which sources of fertilizers were randomly assigned and each subplot were subdivided into six subsubplots measuring $3 \mathrm{~m} \mathrm{x} 4 \mathrm{~m}$ or $12 \mathrm{sq} \mathrm{m}$ for the allocation of insecticide sources that were used. The randomization process was done separately and independently for each block. The experimental field layout and overview are shown in (Figures 2 and 3).

The treatments used were the following:

Mainplot:

Factor A - Inoculation

$\mathrm{A}_{1}$ - Inoculated

$\mathrm{A}_{2}$ - Non-inoculated

Sub-plot:

Factor B - Sources of fertilizers

$\mathrm{B}_{1}-$ Control (No treatment) 
$\mathrm{B}_{2}-1413.6 \mathrm{~kg}$ Vermicompost $+140 \mathrm{~kg}$ Urea/ha

$\mathrm{B}_{3}-571.43 \mathrm{~kg}$ GreenlB ${ }_{4}-192.86 \mathrm{~kg}$ 14-14-14 + 140kg Urea/ha

Sub-sub plot:

Factor C:- Sources of insecticides

$\mathrm{C}_{1}$ - Control (No Treatment)

$\mathrm{C}_{2}-1041.67 \mathrm{li}$ Neem crude extract/ha

$\mathrm{C}_{3}-1041.67$ li Makabuhay crude extract/ha

$\mathrm{C}_{4}-1041.67$ li Made de Cacao crude extract/ha

$\mathrm{C}_{5}$ - 1041.67li Marigold crude extract/

$\mathrm{C}_{6}-1041.67 \mathrm{li}$ Lannate crude extract/ha

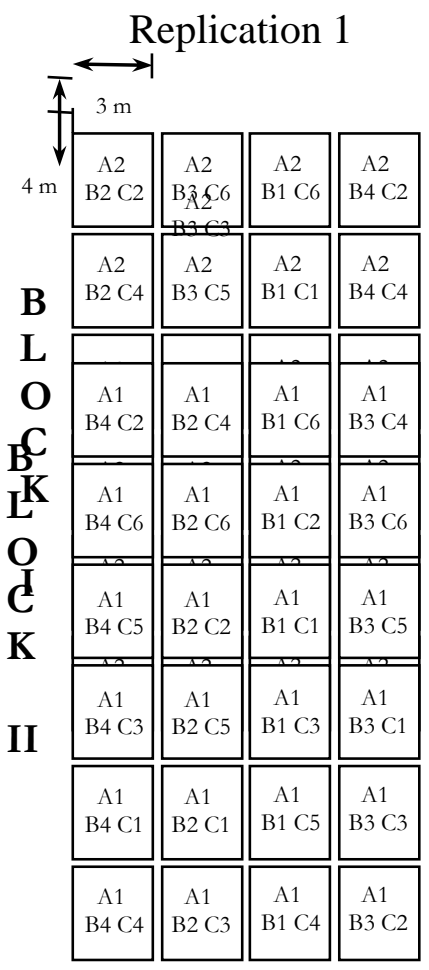

Replication 2

\begin{tabular}{|c|c|c|c|}
\hline $\begin{array}{c}\text { A1 } \\
\text { B4 C3 }\end{array}$ & $\begin{array}{c}\text { A1 } \\
\text { B2 C4 }\end{array}$ & $\begin{array}{c}\text { A1 } \\
\text { B1 C6 }\end{array}$ & 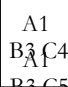 \\
\hline $\begin{array}{c}\text { A1 } \\
\text { B4 C6 }\end{array}$ & $\begin{array}{c}\text { A1 } \\
\text { B2 C2 }\end{array}$ & $\begin{array}{c}\text { A1 } \\
\text { BA1 C5 } \\
\text { B1 C4 }\end{array}$ & $\begin{array}{c}\text { A1 } \\
\text { B3 C1 }\end{array}$ \\
\hline & & & \\
\hline $\begin{array}{c}\text { A2 } \\
\text { B3 C2 }\end{array}$ & $\begin{array}{c}\mathrm{A} 2 \\
\mathrm{~B} 4 \mathrm{C} 4\end{array}$ & $\begin{array}{c}\text { A2 } \\
\text { B1 C1 }\end{array}$ & $\begin{array}{c}\text { A2 } \\
\text { B2 C4 }\end{array}$ \\
\hline $\begin{array}{c}\text { A2 } \\
\text { B3 C6 }\end{array}$ & $\begin{array}{c}\mathrm{A} 2 \\
\mathrm{~B} 4 \mathrm{C} 6\end{array}$ & $\begin{array}{c}\text { A2 } \\
\text { B1 C4 }\end{array}$ & $\begin{array}{c}\text { A2 } \\
\text { B2 C1 }\end{array}$ \\
\hline $\begin{array}{c}\text { A2 } \\
\text { B3 C5 }\end{array}$ & $\begin{array}{c}\text { A2 } \\
\text { B4 C1 }\end{array}$ & $\begin{array}{c}\text { A2 } \\
\text { B1 C6 }\end{array}$ & $\begin{array}{c}\text { A2 } \\
\text { B2 C2 }\end{array}$ \\
\hline $\begin{array}{c}\text { A2 } \\
\text { B3 C3 }\end{array}$ & $\begin{array}{c}\text { A2 } \\
\text { B4 C3 }\end{array}$ & $\begin{array}{c}\text { A2 } \\
\text { B1 C3 }\end{array}$ & $\begin{array}{c}\text { A2 } \\
\text { B2 C6 }\end{array}$ \\
\hline $\begin{array}{c}\text { A2 } \\
\text { B3 C4 }\end{array}$ & $\begin{array}{c}\mathrm{A} 2 \\
\mathrm{~B} 4 \mathrm{C} 5\end{array}$ & $\begin{array}{c}\mathrm{A} 2 \\
\mathrm{~B} 1 \mathrm{C} 2\end{array}$ & $\begin{array}{c}\text { A2 } \\
\text { B2 C5 }\end{array}$ \\
\hline $\begin{array}{c}\text { A2 } \\
\text { B3 C1 }\end{array}$ & $\begin{array}{c}\mathrm{A} 2 \\
\mathrm{~B} 4 \mathrm{C} 2\end{array}$ & $\begin{array}{c}\text { A2 } \\
\text { B1 C5 }\end{array}$ & $\begin{array}{c}\text { A2 } \\
\text { B2 C3 }\end{array}$ \\
\hline
\end{tabular}

Replication 3

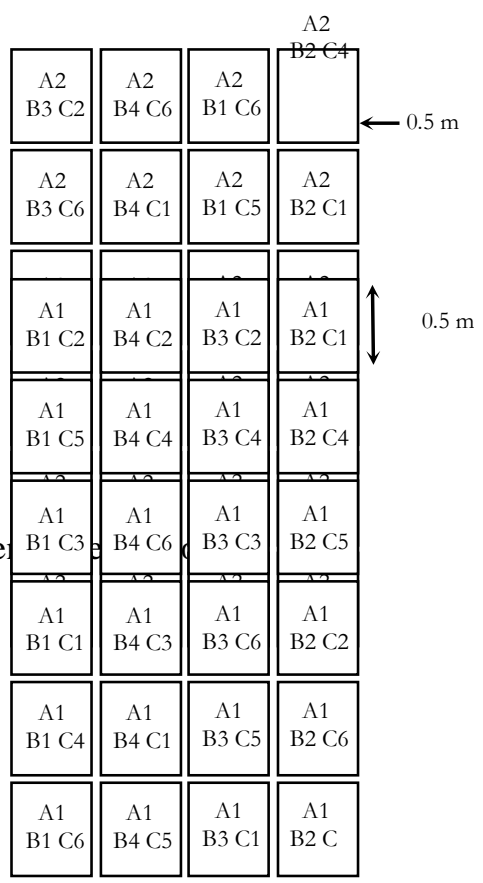

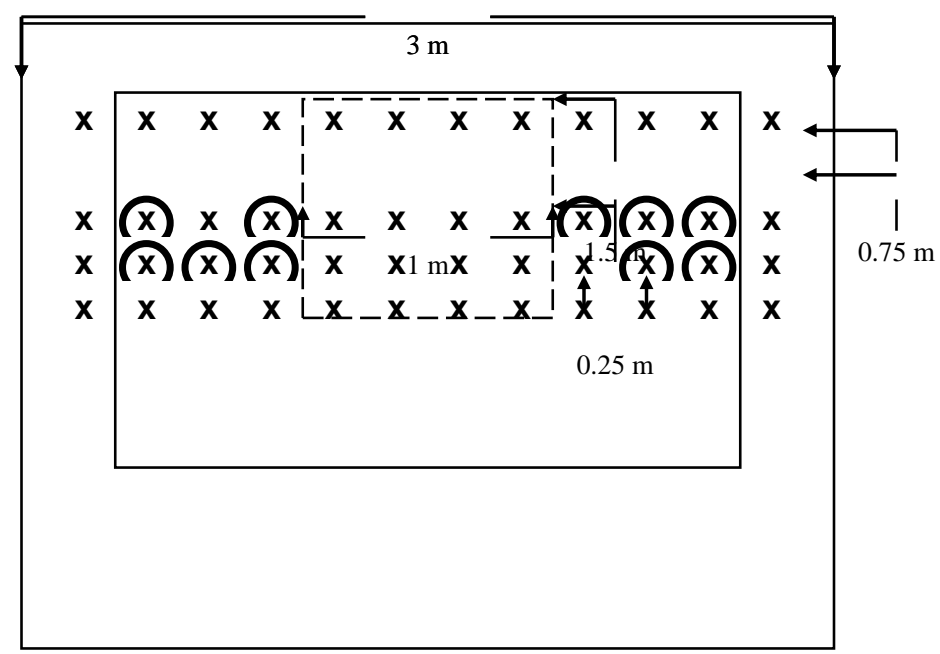

Figure 3:- Overview of sub-sub-plot. 
Legend:

\begin{tabular}{ll}
\hline & border plants \\
ten (10) representative samples
\end{tabular}

\section{Subject of the Study:-}

Corn, according to the Bureau of Plant Industry (BPI), grows best in soil with deep, medium-textured, high in organic matter, well drained, with a high water-holding capacity and $\mathrm{pH}$ value ranging from $5.3-6.0$. It is a monotypic hub belonging to the grass family, genus Zea and species mays with tall culm, unisexual spikelets, with the male flowers above the female, long, narrow leaves with parallel veins, and fibrous root system.

\section{Procedure of the Study:-}

Composite soil sampling was used.

\section{Land Preparation:-}

The experimental area was prepared 3 weeks before planting.

Plowing was done twice

A day before planting, furrows were prepared

\section{Application of Fertilizer Treatments;-}

The amount of fertilizer materials applied per treatment was based on the result of the chemical analysis of the soil on which the recommended rate was 90-30-20. The amounts of fertilizer materials for fertilizer sources were as given above.

\section{Planting:-}

Seeds of Super Sweet EW variety were used. The seeds used in Factor A were inoculated and non-inoculated.

\section{Application of Insecticides:-}

Insecticides treatments were sprayed separately with the use of knapsack sprayer. The application of insecticides was done on the whorling stage of corn plants.

\section{Collection and Preparation of Bio-organic Insecticide:-}

All leaves of plants used in this study were collected from Brgy. Maytalang I, Lumban, Laguna and its nearby communities. Madre de Cacao Leaves (Gliricidia sepium) Extract and Neem Tree_Leaves (Azadirachta indica) Extract, Marigold Leaves (Calendula officinalis) Extract, Makabuhay Vine (Tinospora rumphii) Extract. These were prepared following the procedures specified by PCARRD (1996) as follows: Leaves weighing 2,000g per kind was added to $1000 \mathrm{ml}$ of water, macerated with the use of warring blender and osterized to obtain a homogenous mixture. The mixture was soaked overnight then filtered with the use of cheese cloth. The filtrate served as the crude concentrated extract which was diluted separately with water at the rate of $1 \mathrm{~L}$ per $15 \mathrm{~L}$ of water.

\section{Cultural Management of the Plant:-} Watering and Irrigation:-

Watering was done everyday using sprinkler until 10 days after planting. Application of water through furrow irrigation was done 15 days after planting to ensure that the soil moisture is adequate to effect seedling growth and development then repeated at intervals up to 64 days after planting.

\section{Weeding and Cultivation:-}

Off-barring cultivation was done two weeks after planting and hilling up 30 days after planting to loosen soil surface and control weeds. Spot weeding by hand pulling was done from time-to-time to avoid competition with corn plants for nutrients, water, light, and space. 


\section{Harvesting:-}

Harvesting was done by handpicking when the cobs, husks, and shanks are fully developed and when milky substance exudes when grains were pressed with the fingernail.

\section{Data Gathered:-}

1. Average plant height at maturity - the height of corn plant in $\mathrm{cm}$ was taken by measuring from the surface of the ground up to the top of tallest leaf or tassel (for mature corn plant) using a meter stick.

2. Economic yield - the weight of corn ears/1.5 sq m harvest area excluding border plants in all four sides of a plot.

3. Days of silking - the number of days from seeding up to 50\% silking/plot was measured.

4. Number of days to maturity - the number of days from seeding up to $90 \%$ maturity was recorded.

5. Agronomic characteristics were taken from the ten representative samples per treatment per replication outside the sample harvest as follows:

1. Average number of corn ear per plant. This was taken from the ten representative samples by counting.

2. Average length of corn ear. This was taken by measuring the ten (10) unhusked corn ears per treatment per replication from end-to-end in $\mathrm{cm}$ with the use of a meter stick.

3. Average diameter of the corn ear. The diameters of the unhusked corn ears were taken at the middle of the cob with use of a vernier caliper from the 10 samples per replication.

4. Average number of kernels per corn ear. This was calculated from the 10 representative samples per replication.

6. Weight of harvested corn ear. This was taken from $1.5 \mathrm{sq} \mathrm{m}$ harvest area at the center of each plot.

7. Insect infestation. Scouting the field from time to time to monitor insect pests that attacked the plants anytime during its growth stages. The growth stages include the following:

1. Emergence to whorling (up to 30 days from emergence). Identification of insect pests attacking the underground and above ground parts of corn was conducted up to 30 days from emergence by observing the symptoms exhibited by the plants like stunted growth, patches of yellowing plants in the field, yellowing of the youngest leaves, etc.

2. Whorling to silking. Insects attacking the stalk, corn ear silk and tassels were determined, identified, and counted 20 - 68 days after emergence.

3. Silking to maturity. Insects attacking corn silk at maturity were determined, identified, and counted 20-68 days after emergence. Pests for each growth stages were measured by visual rating of damaged plants.

8. Field screening of pesticides (botanical based insecticides) applied in the corn plant. Effectivity of pesticides used in this study were assessed based on the type of pests, nature of damage, stage of plant growth, and damage assessment, which includes the following data:

1. total number of larvae per plant

2. total number of borers per stem

3. total number of nymphs per corn ear

4. total number of nymphs per plant

\section{Supplies and Materials:-}

The following materials were used in the conduct of this study:

1. Corn variety. Supersweet EW corn variety was used. This was bought from the agricultural supply located at the experimental area in Lumban, Laguna.

2. Inoculant. Bio-N inoculant was availed from the Institute of Biotechnology and Microbiology (BIOTECH) of UP Los Baños.

3. Fertilizers

Vermicompost - is humus produced in vermicomposting that was applied in each hole to provide the nutrients. It contains Nitrogen - $1.91 \%$, Phosphorus - $0.28 \%$, Potassium - $0.20 \%$.

Greenland fertilizer - a fertilizer produced by composting chicken manure. This was also applied in each hole to provide the nutrients. It contains Nitrogen - 1.05\%, Phosphorus - 5\%, Potassium - 3.5\%.

2. Botanical insecticides. These are the botanical plants with insecticidal properties sprayed on corn plants to control insect pests. This comprises of leaf extracts of Madre de cacao (Glericidia sepium); Makabuhay vine (Tinospora rumphii); Neem tree (Azadirachta indica) leaves; and Marigold (Calendula officinalis) Leaves.

3. Sprayer. There were 5 sprayers used to avoid chemical reactions among treatments. 
4. Weighing scale. This was used to measure the organic and inorganic fertilizers applied on corn plants and to measure the weight of harvested corn per $1.5 \mathrm{~m}^{2}$ harvest area.

5. Meter stick. This was used to measure the average height of corn plant in $\mathrm{cm}$.

6. Steel tape. This was used in measuring the field layout of the experimental area.

7. Vernier caliper. This was used to determine the diameter of corn ears in $\mathrm{mm}$.

8. Electric blender. This was used to extract juice of the neem, madre de cacao, makabuhay and marigold.

\section{Statistical Treatment:-}

Data gathered on the average plant height, number of days to silking stage, number of corn ear/plant, number of kernels/ear, length and diameter of ear, yield/1.5 sq m harvest area, insect infestation, insect population, and pesticides screening were analyzed using Analysis of Variance (ANOVA) of the split-split plot design. Significant results in ANOVA were subjected to further statistical analysis using the Duncans' Multiple Range Test (DMRT).

\section{Results And Discussion:- \\ Plant Height:-}

The height of corn plants at maturity was highly affected by Factor B (sources of fertilizers). $\mathrm{B}_{4}$ and $\mathrm{B}_{3}$ were statistically similar and produced the tallest corn plants. Factors A and C did not significantly affect plant height.

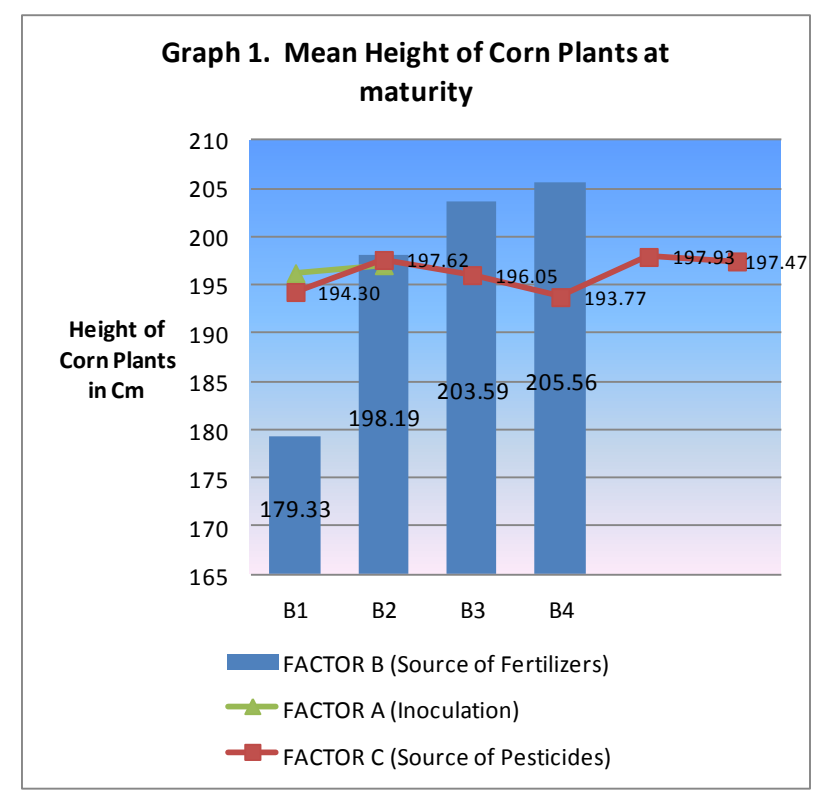

\section{Number of Days from Seeding to 50\% Silking:-}

Unlike factors A and C, factor B (sources of fertilizers) exerted highly significant differences among the treatment mean number of days from seeding to 50 percent silking. The shortest number of days (53.11) was observed in $\mathrm{B}_{4}$ while the longest days was observed in $\mathrm{B}_{1}$ (Control/No Treatment) with 64 days,

The study found that application of organic and inorganic fertilizers used in this study significantly shortened the number of days to 50 percent silking of test corn plants. 


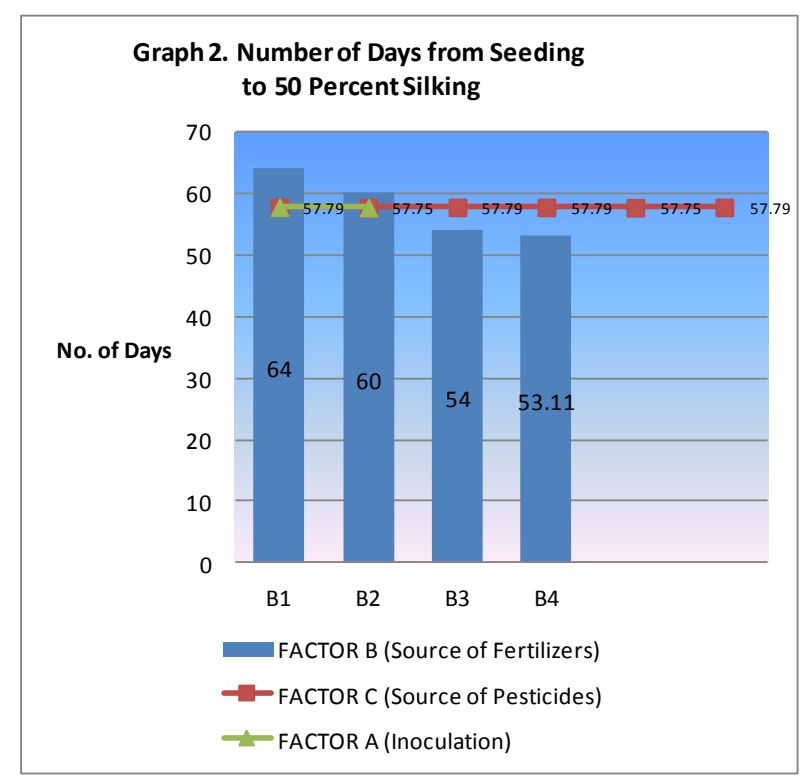

Number of Corn Ears per Plant.:-

All fertilizer-treated plants had significantly higher number of corn ears per plant than the control plants. $\mathrm{B}_{4}$ and $\mathrm{B}_{2}$ were statistically similar and both significantly differed from $\mathrm{B}_{3}$. with means of $1.30,1.17$ and 1.15 , respectively. The grand mean was 1.17 number of corn ears per plant.

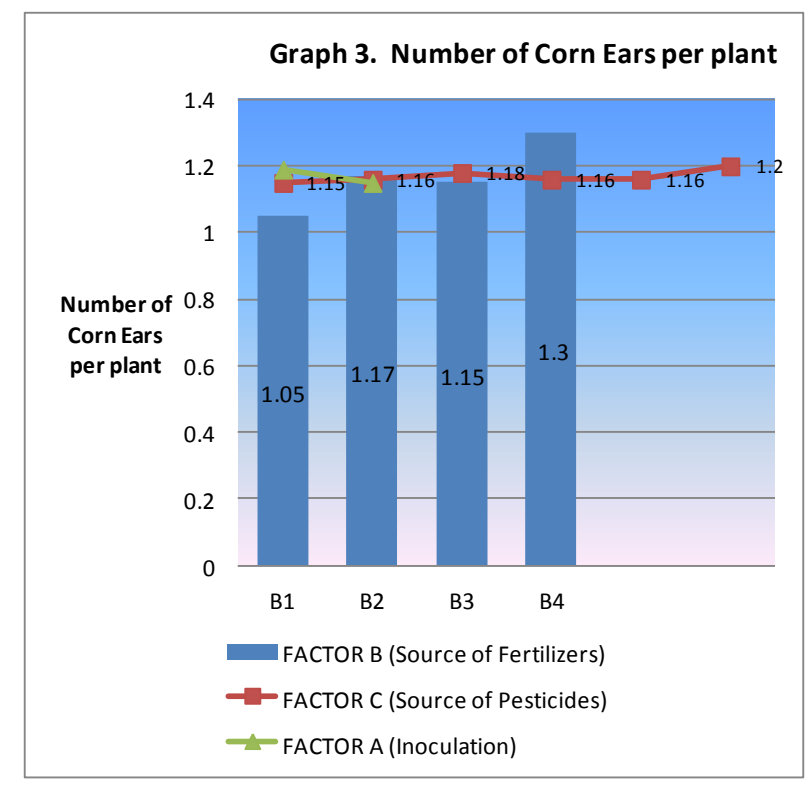

\section{Length of Unhusked Corn Ear:-}

$\mathrm{B}_{3}$ and $\mathrm{B}_{2}$ were statistically similar and both were significantly had longer unhusked corn ear than $\mathrm{B}_{4}$ where all fertilizer-treated plants had significantly longer unhusked corn than the $\mathrm{B}_{1}$ (control plants) with means of 33.53 , $33.29,31.99$ and 28.07 , respectively with a. grand mean length of $31.95 \mathrm{~cm}$. 


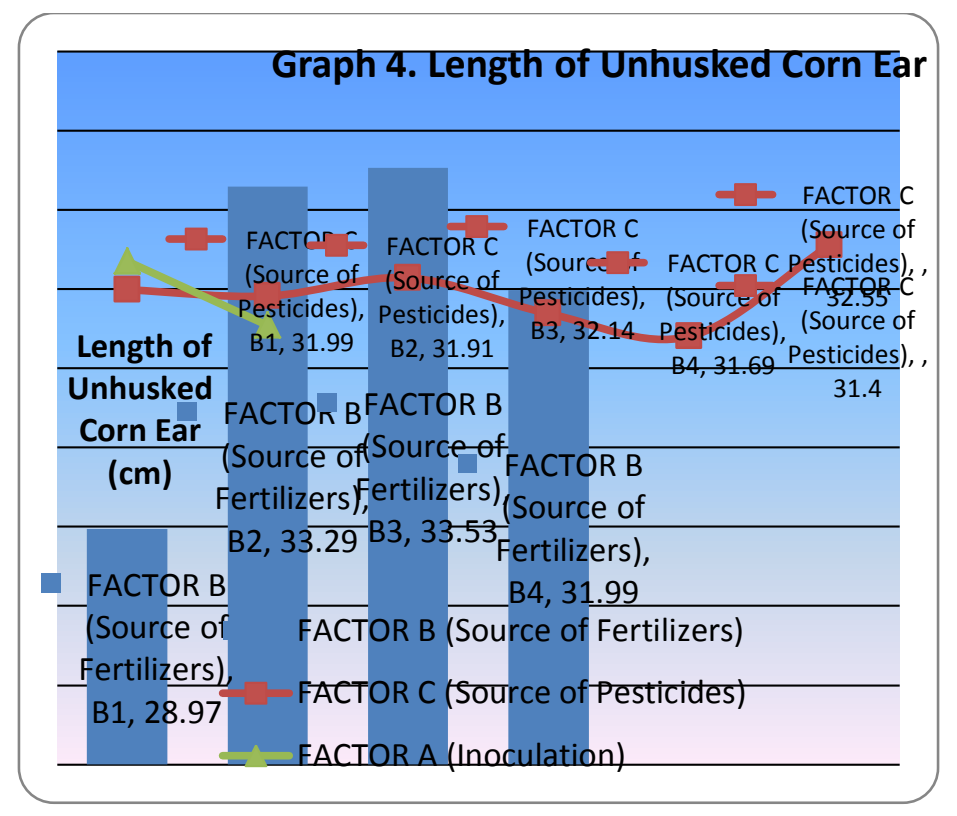

Diameter of Unhusked Corn Ear:-

$\mathrm{B}_{3}$ and $\mathrm{B}_{2}$ were statistically similar and both were significantly had larger diameters of unhusked corn ear than $\mathrm{B}_{4}$ where all fertilizer-treated plants had significantly larger mean diameter of unhusked corn than the control plants with mean diameters of $49.63,49.19,46.61$ and 44.71 millimeters with a grand mean of 46.60 millimeters.. There was significant interactions among factors $\mathrm{A}$ (inoculation), $\mathrm{B}$ (sources of fertilizers) and $\mathrm{C}$ (sources of pesticides).

\section{Number of Kernels per Corn Ear:-}

No significant difference were detected due factors A (inoculation), B (source of fertilizers) and C (source of pesticides); all the observed F-values of $0.23,1.50$ and 1.12 being lower than the critical F-values 18.51, 4.76 and 2.33 , respectively; with a grand mean of 529.99 kernels per corn ear.

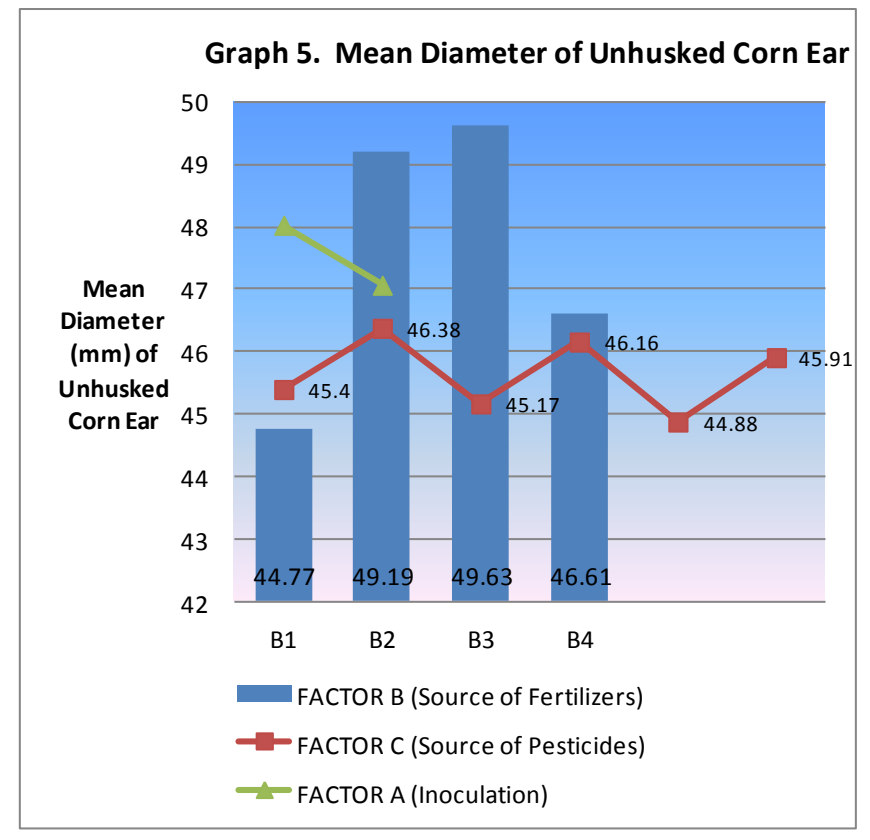

Yield of unhusked Corn Ears per 1.5 sq meters Harvest Area:-

There was highly significant difference among the treatment mean yield of unhusked corn ears in kilograms per 1.5 sqm of harvest area as affected by factor B(sources of fertilizers). The best yield of unhusked corn in kilograms can 
be obtained with application of $\mathrm{B}_{4}$ with mean yield of $3.57 \mathrm{~kg} / 1.5 \mathrm{sqm}$. Application of either $\mathrm{B}_{3}$ or $\mathrm{B}_{2}$ will also significantly give better yield than the control. With means of $3.12,3.11$ and $2.52 \mathrm{kgs}$ per $1.5 \mathrm{sq} \mathrm{m}$. respectivy with a grand mean of $3.02 \mathrm{kgs}$.

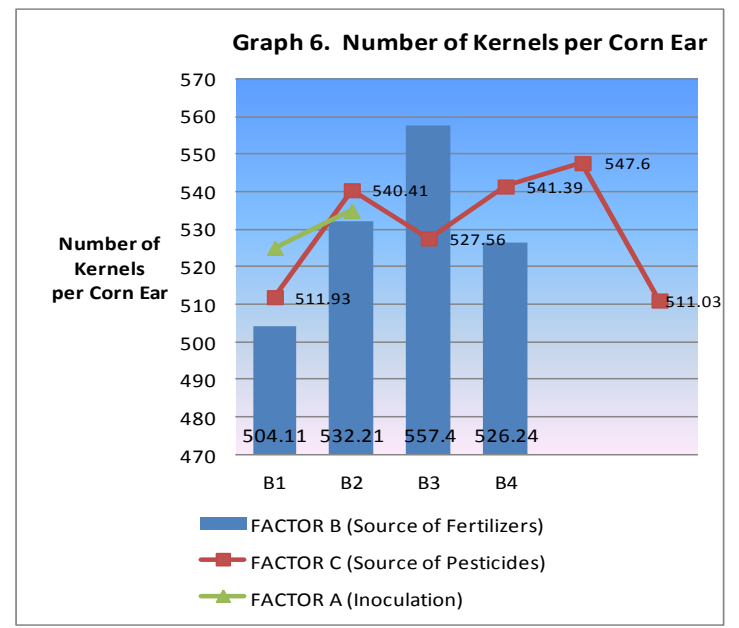

\section{Computed Yield of Unhusked Corn Ears per Hectare:-}

$B_{4}$ yielded 23.18 tons of unhusked corn ears per hectare which was significantly greater than $B_{3}$ and $B_{2}$ with 20.82 and 20.72 tons per ha. which were statistically similar and significantly higher than the $\mathrm{B}_{1}$ (control) with computed yield of 16.81 tons per hectare.
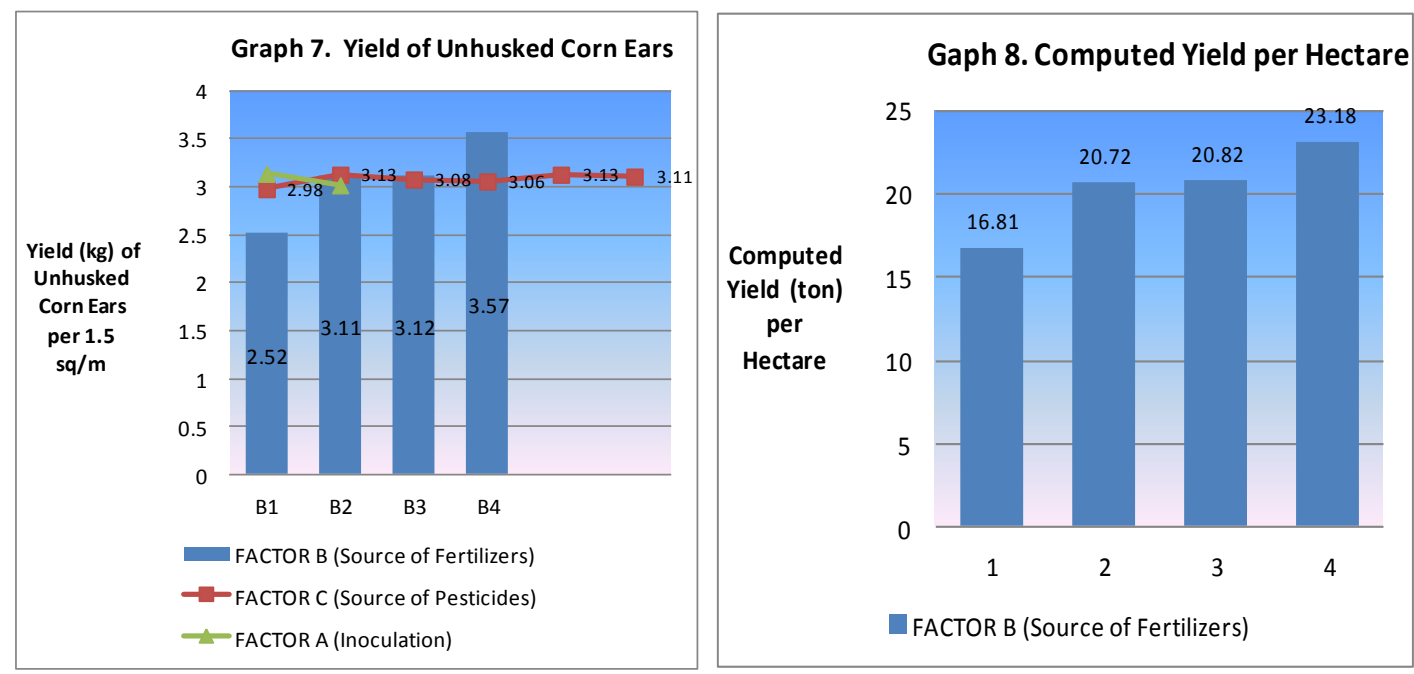

\section{Insect Infestation from Emergence to Whorling;-}

The findings showed that aside from C6 (application of Lannate) which gave the most significant effect on the control of insects, $\mathrm{C}_{3}, \mathrm{C}_{2}, \mathrm{C}_{5}$ and $\mathrm{C}_{4}$ crude extracts which were found to be statistically similar were all significantly different from $\mathrm{C}_{1}$ (control). Thus, the study further showed that from emergence to whorling stage, lannate and the plant crude extracts used in this study can significantly reduce insect infestation. 


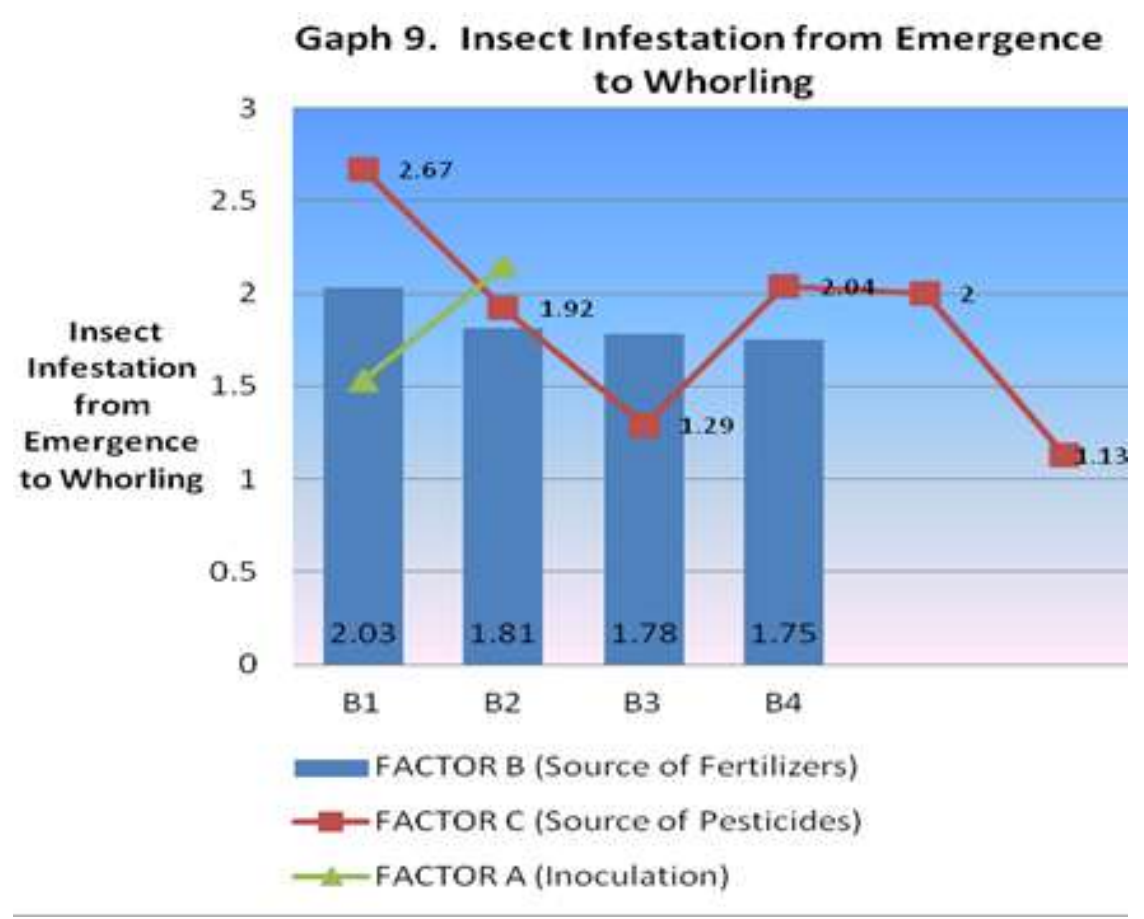

\section{Insect Infestation from Whorling to Silking:-}

$\mathrm{C}_{6}$ and $\mathrm{C}_{3}$ which were statistically similar with a mean of 1.46 and 1.63 , respectively, gave the least insect infestation from whorling to silking. Both $\mathrm{C}_{4}$ and $\mathrm{C}_{3}$ significantly differed from the rest of the pesticide treatments where $\mathrm{C}_{2}, \mathrm{C}_{4}$ and $\mathrm{C}_{5}$ were statistically similar and also significantly differed from $\mathrm{C}_{1}$ (control) with means of 2.50 , 2.54, 2.54 and 3.04, respectively. This showed the effectiveness of lannate, makabuhay, madre de cacao and marigold crude extracts against insect infestation from whorling to silking stage.

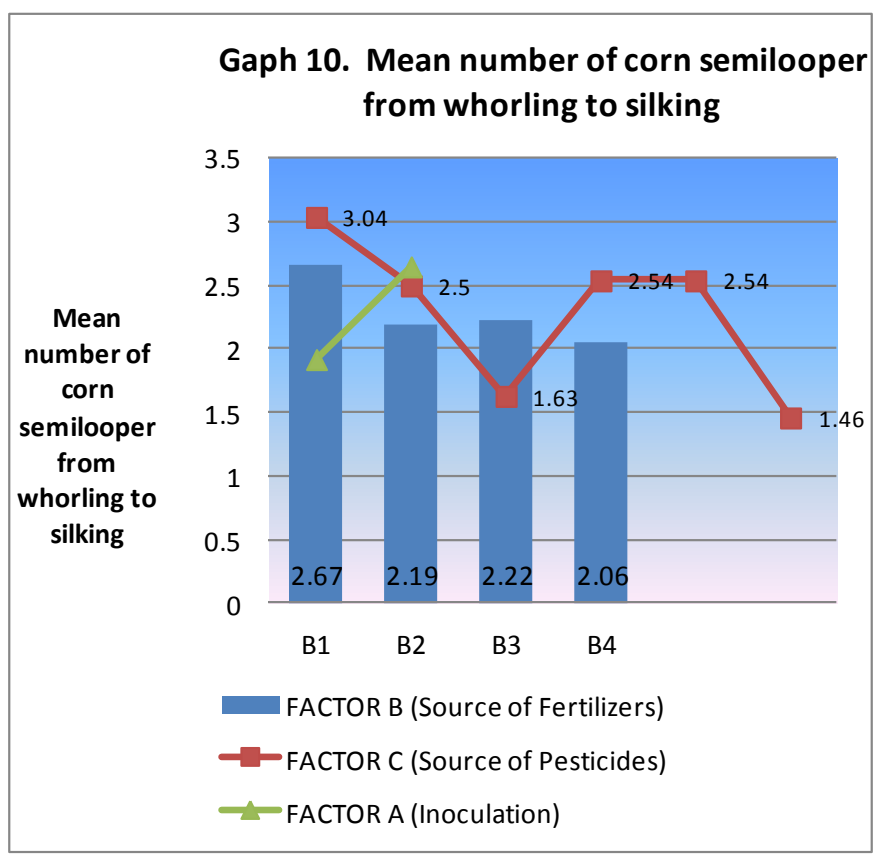

Insect Infestation from Silking to Maturity:-

At this stage, the effectiveness of lannate, makabuhay, madre de cacao and marigold crude extracts against insect infestation was again demonstrated. It can be surmised that from pre-emergence to maturity, the effectiveness of 
lannate, makabuhay, madre de cacao and marigold crude extracts against insect infestation was proven with high degree of certainty.
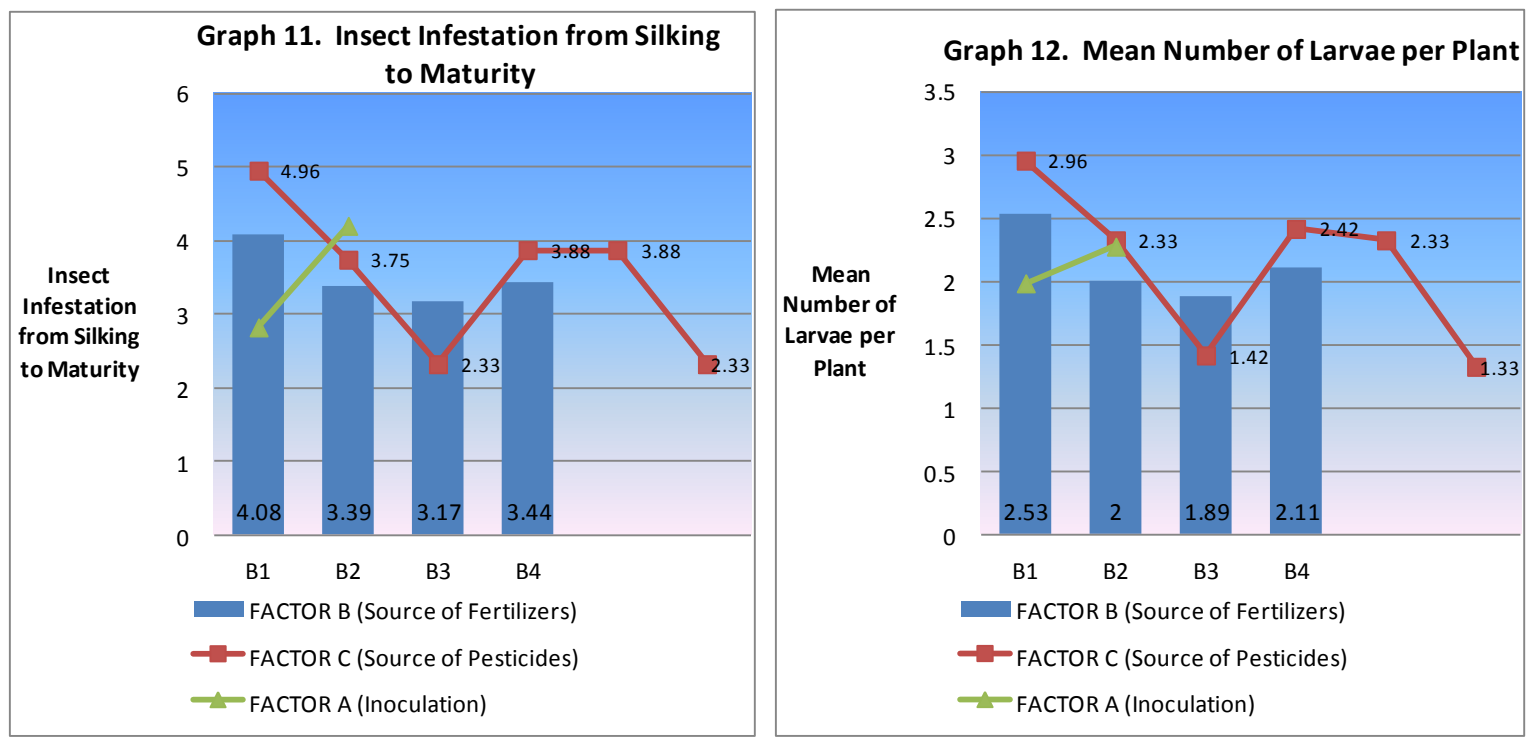

\section{Number of Borers per Stem:-}

Similar trends in effectiveness and performance of the different pesticide treatments to reduce insect infestation including stem borers were observed. It appeared that $\mathrm{C}_{3}$ was as effective as $\mathrm{C}_{6}$.

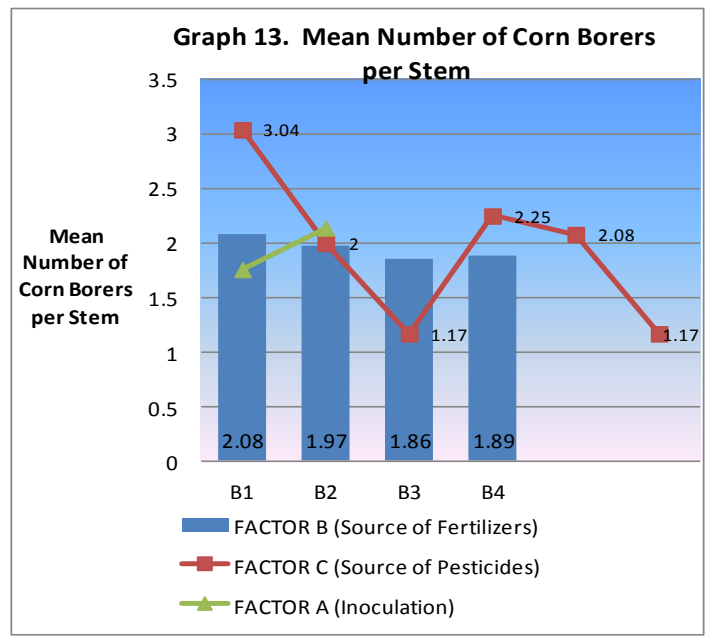

\section{Number of Nymphs per Corn Ear:-}

The findings revealed that $\mathrm{C}_{3}$ was the most effective by having the least mean number of nymphs per corn ear; followed by $\mathrm{C}_{6}$ with the former significantly more effective than the latter. Both lannate and makabuhay crude extract were significantly better than the other treatments: neem, marigold and madre cacao crude extracts which were statistically similar among each other but significantly better than the control. 


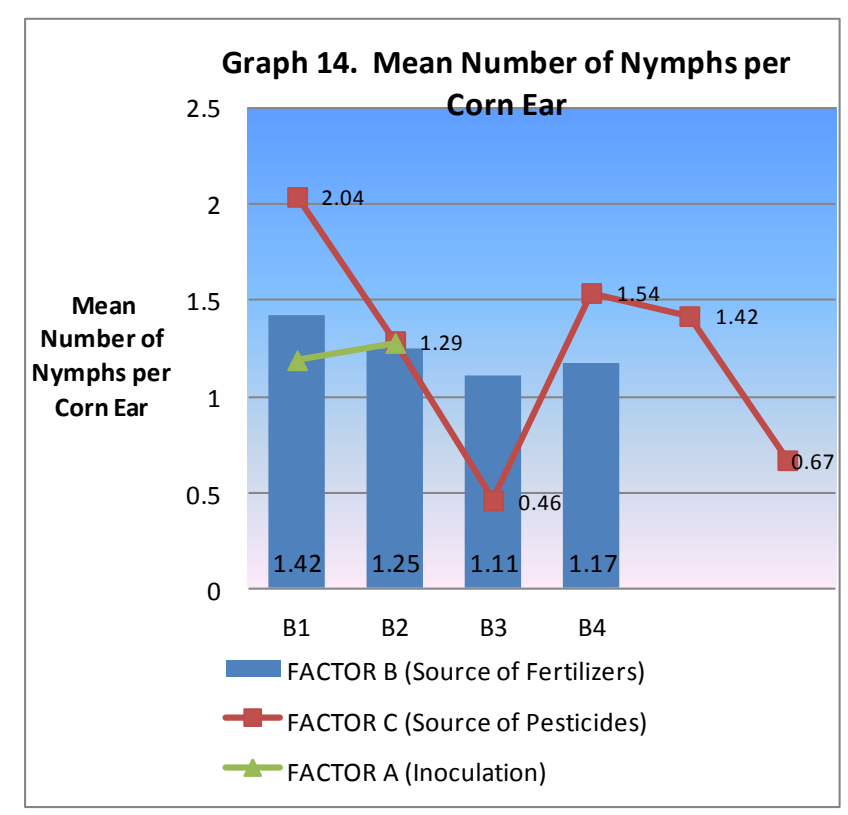

Number of Nymphs per Plant:-

$\mathrm{C}_{3}$ had the least mean number of nymphs per plant of 1.04; followed by $\mathrm{C}_{6}$ with $1.08 . \mathrm{C}_{3}$ and $\mathrm{C}_{6}$ were found to be statistically similar which means that both had the same significant effect over the rest of the treatments. On third was $\mathrm{C}_{5}$ with a mean of 1.63 and significantly better than $\mathrm{C}_{2}$ and $\mathrm{C}_{4}$ which were statistically similar and better than the $\mathrm{C}_{1}$ (control plants) with means of $1.79,1.83$ and 2.33 , respectively.

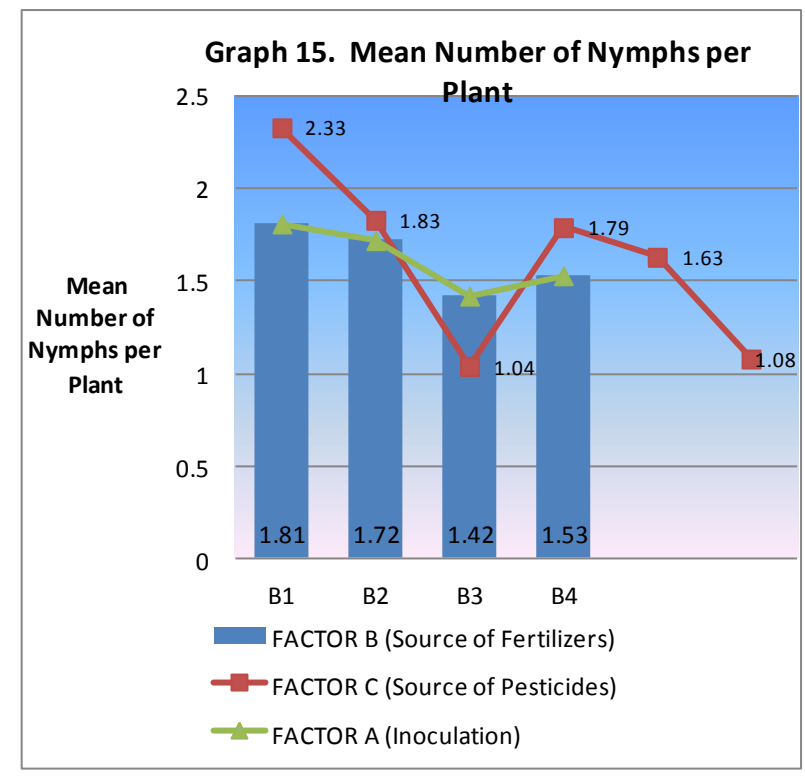

\section{Cost and Return Analysis:-}

$\mathrm{B}_{4}$ gave the highest yield and the most expensive treatment, registered a 382.44 percent return on total expenses. That is, for every peso spent in producing unhusked green corn, one gets a gross return of P3.82. This was followed by $\mathrm{B}_{2}$ with a gross return of $\mathrm{P} 3.56$ for every peso spent; $\mathrm{B}_{3}$ with a gross return of $\mathrm{P} 3.39$ for every peso spent, and $\mathrm{B}_{1}$ (control) the least expensive with a gross return of P3.14 for every peso spent in green corn production. 


\section{Conclusions:-}

Based on the foregoing findings and the hypotheses posited in this study, it was concluded that

1. Inoculation treatment had no significant effect on the growth and yield performance of green corn plant;

2. The sources of fertilizers had significant bearing on the growth and yield performance of green corn plants, specifically with respect to plant height, number of days to 50 percent silking, number of corn ears per plant, length and diameter of unhusked corn ear, yield of unhusked corn ear per 1.5 sq meter harvest area in kilograms and computed yield of unhusked corn ears per hectare in tons and cost and returns per hectare.

3. The sources of pesticides had significant effect on insect infestation and population in all the stages of growth of the corn plant, specifically in insect infestation on emergence to silking, silking to maturity, number of larvae per plant, number of borers per stem, number of nymphs per corn ear and number of nymphs per plant.

4. There were no interaction effects between inoculation and source of fertilizers (AxB); between inoculation and sources of insecticides (AxC) except in number of borers per stem); between sources of fertilizers and insecticides $(\mathrm{BxC})$ except in diameter of unhusked corn ear; and insect infestation at and among inoculation, sources of fertilizers and sources of insecticides.

\section{Recommendations:-}

In the light of the foregoing conclusions, the study recommends the following:

1. Organic fertilizer combined with urea $\mathrm{B}_{3}$ as well as that of Inorganic fertilizer $\mathrm{B}_{4}$ be uses in green corn production in order further as certain the effectiveness and profitability of these fertilizers. Likewise, the study recommends the utilization of these fertilizers in the production of other corn varieties and also to implement these fertilizers in other conditions in order to further gather relevant data that can be used to validate, verify or counter pose the conclusions arrived in this study. At such, these will be more scientific information available that will be useful in invigorating and improving corn production as well as the corn production industry with respect to matters concerning issues of fertilizers.

2. Organic pesticides such as $\mathrm{C}_{3}$ at different levels of concentration of the corn production practices in general as it was found insignificantly effective in this study data and information necessary to validate the conclusion earlier or the otherwise. Further, the study also recommends the utilization of different botanical plants with insecticidal properties in enterprises such as green corn production and other crops in order to collect data and information relevant to promote the country with minimal dependence on artificial pesticides that are at face cost but eventually depletes the natural fertilizer of the soil as well as for natural conservation.

\section{Literature Cited:-}

\section{Books:-}

1. Aganon, Teotimo M., et al. Eds. 2004. Technoguide for Corn Production. Technoguides for Agricultural Production and Livelihood Project. Research, Extension, and Training. CLSU, Muños, Nueva Ecija, pp. 158164.

2. Cosico, W.C. 1991. Guide to Soil and Fertilizer Requirements of Crops. Technology and Livelihood Resource Center and UP Los Baños.

3. Dagoon, J.D. and P.D. Sangatanan 1990. Soils, Fertilizers, and Crops. Quezon City. Rex Printing Co., Inc.

4. Philippine Council for Agriculture, Forestry, and Natural Resources Research and Development PCARRD. 1998. The Philippines Recommended for Soil Fertility Management. PCARRD, Los Baños, Laguna, Philippines.

5. Waage, J. 1997. What does Biotechnology Bring to Integrated Pest Management? Biotechnology and development Monitor No. 32, pp. 19-21.

6. Journals and Magazines:-

7. Aquino, A.P., et al. 2001. "Validating the Promise of Biotechnology: The Case of Multi-location Field Testing of Bt Corn in the Philippines." PCARRD-DOST, Los Baños, Laguna, Philippines.

8. Arceo, Antonieta J. 2008. A Guide for Corn Production. Agricultural Training Institute, Diliman, Quezon City.

9. Eduardo, F. 2000. "Bt Corn Trials Yields Promising Results: Agriculture Monthly Magazine. Manila Bulletin, Intramuros, Manila, Philippines June 2002 IV 6: 15-16.

10. Guerrero III, Rafael D. 2003. "Vermicomposting is Catching on." Agriculture Monthly Magazine. Manila Bulletin, Manila Bulletin, Manila, Philippines, August 2003, VII 8, pp. 18-19.

11. Napoleon, K. 1996. "Pesticide Residues in Food Raise Complex Issues." Agrislope. The Philippine Agribusiness Magazine Basic Publication, Co., Inc., Manila x8:8. 
12. Navarro, M. 2000. "Small Organisms Doing Big Job in Agriculture." Agriculture Monthly Magazine. Manila Bulletin, Intramuros, Manila, Philippines, IV 5: 8-9.

13. Nieves, Allan C. "The Other Insect Pests: Corn Pernthoppers and Leaf Aphids." Agriculture Monthly Magazine. Manila Bulletin: Intramuros, Manila Philippines. January 2009 XIII 1: 38-39.

14. Nieves, Allan C. "The Other Insect Pests 2: Corn Defoliators." Agriculture Monthly Magazine. Manila Bulletin: Intramuros, Manila Philippines. April 2009 XIII 4: 32, 34-35.

15. Ramos, M.G. 2002. "Trichograma and Bio-N Cut Rice and Corn Cost by Half." Agriculture Monthly Magazine. Manila Bulletin, Intramuros, Manila, Philippines March 2002 VI 3: 8-9.

16. Sarian, Zac B. 2009. "Pointers in Growing Sweet Corn." Agriculture Monthly Magazine. Manila Bulletin: Intramuros, Manila, Philippines January 2009 XIII I: 54-56.

17. SEARCA 1998. Catalogue of Conservation Practices for Agriculture on Sloping Land: Biological Nitrogen Fertilizer. U.P. College Los Baños, Laguna, Philippines, pp. 106.

18. Theses

19. Aglian, Fe G. 1998. "Baby Corn Yield of PSB of 93-49 DLU Peas Sweet and Philippine Supersweet No. 1 Azukar as Affected by Different Sources of Fertilizer." Unpublished Master's Thesis, Tarlac College of Agriculture, Camiling, Tarlac.

20. Baliso, A.A. 1995. "Response of Corn to Nitrogen Fertilizer and Green Manure Management." Unpublished Dissertation University of the Philippines, College, Laguna.

21. Corales, A.M. 1996. "Factors Influencing the Utilization of Organic Fertilizers." Unpublished Master's Thesis, CLSU, Muños, Nueva Ecija.

22. Cosico, Theresa Aurora B. 2008. Enhancing the Global Competitiveness of the Philippine Corn Industry Under an Open Trade Regime. Unpublished Masters in Applied Business Economics Thesis, University of Asia and the Pacific, Pasig City.

23. Perolina, L.C. 2001. A Comparative Study on Kakawate and Wild Flower as Green Manures in Corn Organic Farming. Unpublished Thesis, LSPC, Siniloan, Laguna.

24. Viyar, L.D. 2005. Performance of Sweet Corn Intercropped with Mungbean as Affected by Insecticide and Nitrogen Sources. Unpublished Dissertation. URS, Rizal Province. 